\title{
Serbest Zaman Aktivitelerine Katılım Durumlarına Göre Emekli Bireylerin Umutsuzluk Düzeylerinin İncelenmesi
}

\author{
Nilgün Tülüktaş ${ }^{1}$ \\ Doç. Dr. Elif Karagün ${ }^{2 *}$ \\ Onur Kavi ${ }^{3}$
}

Geliş tarihi: 11.10 .2019

Kabul tarihi: 05.12.2019

\section{Atıf bilgisi:}

IBAD Sosyal Bilimler Dergisi

Sayı: $5 \quad$ Sayfa: 587-597

Yıl: 2019 Dönem: Güz

This article was checked by iThenticate. Similarity Index 11\%

\author{
${ }^{1}$ Kocaeli Üniversitesi, Türkiye, \\ nilguntlks@hotmail.com, \\ ORCID ID 0000-0002-9881-0401 \\ ${ }^{2}$ Kocaeli Üniversitesi, Türkiye, \\ ekaragun@kocaeli.edu.tr \\ ORCID ID 0000-0003-1974-4117 \\ ${ }^{3}$ Kocaeli Üniversitesi, Türkiye, \\ onurkavi92@gmail.com
}

ORCID ID 0000-0002-9307-744X

\section{ÖZ}

$\mathrm{Bu}$ araştırmanın amacı, 55 yaş üzeri emekli bireylerin serbest zamanlarında rekreatif etkinliklere katılma durumlarına göre; umutsuzluk düzeylerinin incelenmesidir. Bu amaçla Kocaeli İzmit İlçesi Şehir Merkezinde bulunan emekli evleri, parklar ve kahvehanelerde, emekli olduğunu beyan eden 55 yaş üzeri bireylere araştırmanın amacı açıklanmıștır. Açıklamalardan sonra çalışmaya gönüllü katılmak isteyen 41 kadın ve 39 erkek olmak üzere toplam 80 emekli birey çalışma kapsamına alınmıştır. Gönüllü katılımcılara veri toplama amacı ile; Kişisel Bilgi Formu ve Beck Umutsuzluk Ölçeği (BUO) uygulanmıştır. Uygulama sonucu elde edilen veriler SPSS 21.00 paket programında analiz edilmiştir. Yapılan İstatistiksel analizlerde veriler normal dağılım gösterdiğinden ikili küme karşılaştırmaları için bağımsız gruplar için t testi, üç ve daha fazla küme karşılaştırmaları için tek yönlü Varyans analizi kullanılmıștır. Yapılan analizler sonucunda; serbest zamanlarında etkinliğe katılmayanlar, yaşı 70 ve üzeri olanlar; eğitim seviyesi düşük olanlar, bekarlar, emeklilik öncesi meslekleri olmayıp aktif çalışmayanlar lehine umutsuzluk puanları anlamlı derecede yüksek görülürken; cinsiyet, psikolojik tedavi görme ve gelir durumları açısından bakıldığında anlamlı farklılık görülmemiștir.

Anahtar Sözcükler: umutsuzluk, serbest zaman, aktivite, emekli

Anahtar Kelimeler: 3-5 anahtar kelime yazılmalıdır. Aralarına virgül konmalıdır. 
The Examination of Hopelessness Levels of Retired Individuals Participating and NonParticipating in Recreational Activities

\author{
Nilgün Tülüktaş ${ }^{1}$ \\ Assoc. Prof. Dr. Elif Karagün ${ }^{2 *}$ \\ Onur Kavi ${ }^{3}$
}

First received: 11.10 .2019

Accepted: 05.12.2019

\title{
Citation:
}

IBAD Journal of Social Sciences

Issue: $5 \quad$ Pages: 587-597

Year: 2019 Session: Fall

This article was checked by Ithenticate. Similarity Index 11\%

${ }^{1}$ Kocaeli University, Turkey, nilguntlks@hotmail.com,

\section{ORCID ID 0000-0000-0000-0000}

2Kocaeli University, Turkey, elif.karagun@gmail.com ORCID ID 0000-0003-1974-4117

${ }^{3}$ Kocaeli University, Turkey, onurkavi92@gmail.com ORCID ID 0000-0002-9307-744X

\footnotetext{
* Corresponding Author
}

\begin{abstract}
The aim of this study is to examine the level of hopelessness in 55-year-old (and over) retired individuals according to their participation in recreation activities in their free times. In accordance with this aim, 55-year-olds, who declared that they are retired, were informed about the aim of the study in retirement community houses, parks and cafés in the city centre of Izmit, Kocaeli Province. After the explanations about the study, 80 (41 females and 39 males) retired individuals who are willing to join, were included in the study. Volunteers were applied Personal Information Form and Beck Hopelessness Scale (BHS) with the aim of collecting the data of the study. The data that was collected at the end of the study was analysed with SPSS21.00 package programme. As the data showed normal distribution in statistical analysis, $t$ test was applied to independent groups for paired-cluster comparisons. However, one - way ANOVA was used for three and more cluster comparisons. At the end of the analysis, hopelessness scores were observed to be significantly high in favour of those who do not participate in any activities in their leisure time, who are over 70, whose educational level is low, who are unmarried, and the ones who hadn't worked actively before retirement. However, no significant difference was found when their gender or their income was taken into consideration. In addition, whether they had any psychological treatment or not didn2t show any significant difference.
\end{abstract}

Key Words: hopelessness, leisure time, activity, retired 


\section{GİRIŞ}

Umut, bir nevi güç olarak nitelendirilmiş, yaşamak ve mevcut engellerle başa çıkmak için gerekli enerjiyi veren, gelecekteki hedefe yönlendiren bir tür motive edici yönü olduğundan da söz edilmiştir (Öz, 2010). Motive edici bu durumun da aslında hayata dair bir tür güven duyma olduğu, hayata yönelik güveni kaybeden ve çözüm yolu bulamayan kişilerin de umudunu kaybettikleri, ancak umutlarının olması halinde ise bireylerin istek ve cesaret içinde tüm güçlükleri yenebilecekleri de belirtilmiștir (Kocaman, 2008). Umut, bir tür yaşam enerjisi iken; umutsuzluk ise, belli bir amacı gerçekleştirmede olumsuz beklenti ve çözümsüzlük duyguları olarak, sıfirdan az olan beklentiler şeklinde açıklanmıştır (Dilbaz ve Seber, 1993). Ayrıca umutsuzluğun, insanın alternatiflerinin olmadığı zaman veya sinırlı sayıda alternatifi olduğunda, enerjisini harekete geçiremediğinde öznel bir duygu olduğu şeklinde de açıklamalar yapılmıştır (Yıldırım, 2015). Pek çok çalışmada umutsuzluk; bireylerin gelecek hakkında olumsuz bir beklenti içine girmesi şeklinde açıklanmıştır. Ayrıca bireylerdeki bu umutsuzluğun da bilişsel çarpıtmalar veya gerçekçi olmayan düşünceler yoluyla arttığı vurgulanmıştır (Durak ve Palabıyıkoğlu, 1994). Umut kavramında hedeflere ulaşmak için uygulamaya konulan planların başarılacağı öngörüsü varken; umutsuzlukta başarısızlık yargısının olduğu ifade edilmiştir (Kutlu, 1998).

Dünya genelinde, doğurganlığın azalması ve ölüm sonucu nüfusun yaşlandığı, 60 yaş ve üzeri kişilerin 2013 yılında dünya nüfusunun\% 11,7'sini temsil ettiği, 2050 yılına kadar bu sayının \% 21,1'e ulaşmas1 beklendiği ve 60 yaş ve üzeri kişilerin \% 50'sinde sosyal izolasyon riski olduğu bildirilmiştir (Landeiro, Barrows, Musson, Gray and Leal, 2016). Dünyada insan nüfusu giderek yaşlandığı ve yaşlanma ile birlikte sağlık, sosyal ve ekonomik problemler görüldüğ̈̈, görülen bu problemlerin yanında yaşlı olmaya ve buna uyum sağlanmaya dönük bir takım sorunlar ortaya çıktığı da bildirilmiştir (Bilir, Paksoy ve Erbaydar, 2015). Pek çok sorun ortaya çıkmasıyla birlikte yaşlılık dönemi araştırılmaya başlanmıştır (World Health Organization [WHO], 2015). Yaşl1lıkla birlikte ortaya çıkan pek çok sorun içerisinde; sağlık ve fiziksel olanların yanında sosyal ve duygusal değişimler de önemli görülmüştür. Yaşlılıkta ailesel değişimler, emeklilik, sağlık sorunları ve fiziksel kısıtlılıklar ile birlikte sosyal yaşamda da bazı değişiklikler yaşanmaktadır. Emeklilik, eş ölümü, çekirdek aile haline gelme, fiziksel kısıtlılıklar nedeniyle yaşlı bireylerin sosyal çevreden uzaklaşarak kendini dış çevreden soyutladığı da görülmektedir (Şahin, 2019). Kendini dış çevreden soyutlama gibi değişimler, hayata bakışı önemli ölçüde etkileyebilecek bir duygu olan umutsuzluğa da yol açabildiği belirtilmiştir (Aslan ve Hocaoğlu, 2017; Öz, 2002).

Her insanın kalıtsal donanımı, yaşam biçimi, sosyal hayatı, fiziksel ve ruhsal hastalıkları farklı biçimde yaşlanmasına neden olduğu açıklanmıştır (Özben, 2008). Yaş dönem özellikleri gereği yaşlanmayla birlikte kişilerin yaşamlarında ortaya çıkan değişikliklere uyum sağlama çalışmaları, giderek yalnızlaşma ve umutsuzluk düzeylerini de arttıracağı ileri sürülmüştür. Amerikan Psikoloji Birliği, pek çok belirtinin yanında sosyal ortamlardan kaçınmanın da umutsuzluğun bir tür belirtilerinden olduğunu bildirmiştir (Tanç, 1999).

Yaşlanan insanların giderek eve daha bağımlı oldukları, farklı nedenlerle sosyal ortamdan kaçındıkları için bazı psikolojik sorun yanında sosyal açıdan da sorun yaşadıkları ve yaşlı bireylerde yalnızlığın mortaliteyi artırdığı da iddia edilmiştir (Steptoe, Shankar, Demakakos and Wardle, 2013). Emeklilikle birlikte sosyal ortamdan çekilme, yaşla birlikte değişen aile ve yaşam koşulları, ölüm oranları da göz önüne alındığında; umut duygusunun çalışılması önemli hale geldiği düşünülmüştür. $\mathrm{Bu}$ açıdan 55 yaş üzeri emekli olan bireylerde emeklilikle birlikte umutsuzluk duygusunun değişip değişmediği merak edilmiştir. Bu açıdan emeklilerde umutsuzluğun ne durumda olduğu belirlenmek istenmiştir. Özellikle bu yaş grubu bireylerin sosyalleşmelerinin bir göstergesi olan serbest zamanlarında etkinliğe katılıp katılmadıkları ve bu katılımla birlikte umutsuzluk duygusunun değişip değişmediği öğrenilmeye çalışılmıştır. Ayrıca emekli olan bireylerin yaşamında serbest zamanın fazlalaşması ve umutsuzluk duygusunun yoğun yaşanması durumu da göz önüne alındığında umutsuzluk ile baş etmede etkisi belirlenen rekreatif aktivitelere katılıma göre umutsuzluk duygusunda bir farklılaşma olup olmadığı araştırılmak istenmiştir.

Tüm bu değerlendirmelerden yola çıkılarak ve 55 yaş üzeri bireylerde umutsuzluk düzeylerinin belirlenerek; sosyo demografik özellikler açısından farklılık gösterip göstermediğinin incelenmesi amaçlanmıştır. 


\section{MATERYAL VE METOD}

\section{Araştırma Grubu}

Araştırma için Kocaeli İzmit İlçesi Şehir Merkezinde bulunan emekli evleri, parklar ve kahveler dolaşılarak, emekli olduğunu beyan eden 55 yaş üzeri bireylere araştırmanın amacı açıklandıktan sonra çalışmaya gönüllü katılmak isteyen 41 kadın ve 39 erkek olmak üzere toplam 80 emekli kişiden oluşmuştur.

\section{Veri Toplama Araçları}

\section{Kişisel Bilgi Formu}

Rekreatif etkinliklere katılıp katılmama, rekreatif etkinliklere katılım var ise ne tür etkinliklere katıldığı gibi değişkenlerin yanı sıra; yaş, cinsiyet, meslek, emeklilik yılı, sosyal güvencesinin olup olmaması, eğitim, medeni durum, kiminle yaşadığı, çocuk sayısı, gelir durumu, psikolojik ya da fiziksel bir hastalığının olup olmamasını belirleyen sorgulayan toplam 17 sorudan oluşmaktadır.

\section{Beck Umutsuzluk Ölçeği}

Beck ve arkadaşları (1974) tarafından geliştirilen, Türkiye için geçerlik ve güvenirlik çalışmaları 1994 yılında Durak tarafından yapılan 20 maddelik kendini değerlendirme türü bir ölçektir (Durak ve Palabıyıkoğlu 1994). Bireyin geleceğe yönelik negatif beklentilerini yansıtan, karamsarlık derecesini belirleyen, "evet", "hayır" şeklinde yanıtlanan, 0-20 aralığında puan alınan ölçeğin "gelecek ile ilgili duygular ve beklentiler", "motivasyon kaybı" ve "umut" olmak üzere üç faktörden oluştuğu bildirilmiştir. Ölçek maddelerinin 11 tanesinde "evet" seçeneği 9 tanesinde ise "hayır" seçeneği 1 puan almaktadır. $1,3,5,6,10,13,15$. ve 19 . sorulara "hayır"; $2,4,7,9,11,12,14,16,17,18$. ve 20 . sorulara ise "evet" yanıtı için birer puan verilmektedir. 0-20 değerleri arasında değişebilen puanlar yüksek olduğunda umutsuzluğu, düşük olduğunda ise umudu göstermektedir (Savaşır ve Şahin,1997).

\section{Verilerin Toplanması}

Araştırma için emeklilerin katılımlarının yoğun olabileceği yerler olan; park, hastane, kahvehanelere gidilerek 55 yaş üzeri olan emekli bireylerle görüşülmüştür. Araştırmanın amacı ve içeriğiyle ilgili bilgilendirme yapıldıktan sonra araştırmaya gönüllü olarak katılmak isteyenlere anketler dağıtılmıştır. Ölçek formlarının doldurulması için 15-20 dakikalık zaman tanınarak doldurulan anketler tekrar araştırmacı tarafindan toplanmıştır. Doldurulan ölçekler kontrol edildiğinde formata uygun doldurulan toplam 80 ölçek değerlendirmeye alınarak analiz edilmiştir.

\section{Verilerin Analizi}

Ölçek uygulamalarında elde edilen veriler SPSS 21.00 Paket programında analiz edildiğinde normal dağılıma uydukları için ikili küme karşılaştırmaları için bağımsız gruplar için " $t$ " testi, üç ve daha fazla küme karşılaştırmaları için tek yönlü varyans analizi kullanılmıştır.

\section{BULGULAR}

Tablo 1. Katılımcıların özelliklerine ilişkin frekans ve yüzdelik dağılımları

\begin{tabular}{cccc}
\hline Değişken & n & \% \\
\hline \multirow{2}{*}{ Emekli Olmadan Önce Ne İş } & Çalışmadım & 20 & 25,0 \\
Yaptığı & Memur & 17 & 21,3 \\
& İşçi & 20 & 25,0 \\
& Serbest Meslek & 12 & 15,0 \\
& Diğer & 11 & 13,8 \\
\hline \multirow{3}{*}{ Kaç Yıldır Emekli Olduğu } & $5-10$ & 19 & 23,8 \\
& $11-15$ & 16 & 20,0 \\
& $16-20$ & 14 & 17,5 \\
& $21-25$ & 21 & 26,3 \\
\hline
\end{tabular}


Emekli olmadan önce yaptıkları iş sorgulandığında \% 25,0 kişi aktif çalışmadığını; \%21,3’ü memur; \% 25 ' $\mathrm{i}$ işçi; \% 15' $\mathrm{i}$ ise serbest meslek; \% 13,8'i ise diğer işlerle ilgilendiğini belirtmiştir.

Katılımcıların büyük çoğunluğu 19 (\% 23,8) kişi 5-10 yıl; 16 (\% 20,0) kişi 11-15 yıl; 14 (\% 17,5) kişi 16-20 yıl; 21(\%26.3) kişi 21-25 yıl; 10 (\% 12,6) kişi ise 26 -30 yıl olduğu tespit edilmiştir.

Tablo 2. Katılımcıların sosyo-demografik özelliklerine ilişkin yüzdelik dağılımları

\begin{tabular}{cccc}
\hline Değişken & n & \% \\
\hline \multirow{2}{*}{ Yaş } & $55-60$ & 19 & 23,8 \\
& $61-65$ & 26 & 32,5 \\
& $66-70$ & 26 & 32,5 \\
Cinsiyet & 70 ve Üzeri & 9 & 11,3 \\
\hline \multirow{2}{*}{ Eğitim Durumu } & Kadın & 41 & 51,2 \\
& Erkek & 39 & 48,8 \\
\hline \multirow{2}{*}{ Medeni Durum } & Okuryazar & 8 & 10,0 \\
& İlk Okul & 25 & 31,3 \\
& Orta Okul & 27 & 33,8 \\
& Lise & 17 & 21,3 \\
Evlilik Durumu & Üniversite & 3 & 3,8 \\
\hline \multirow{2}{*}{ Gelir Düzeyi } & Evli & 52 & 65,0 \\
& Bekar & 28 & 35,0 \\
\hline & Birlikte & 52 & 65,0 \\
& Ayri & 6 & 7,5 \\
& Eşim Vefat Etti & 22 & 27,5 \\
\hline & $1001-1500$ tl & 32 & 40,0 \\
& $1501-2000$ tl & 23 & 28,7 \\
& 2001 ve üzeri & 25 & 31,3 \\
\hline
\end{tabular}

Tablo 2'de yer alan katılımcıların sosyo-demografik yüzdelik dă̆ılımlarından; yaş değişkeni incelendiğinde \% 23,8'i 55-60 yaş arası; \% 32,5'i kişi 61-65 yaş arası; \% 32,5'i 66-70 yaş arası; \% 11,3 'ü ise 70 yaş ve üzeri olduğu görülmüştür.

Cinsiyet açısından \% 51,2'si kadın; \% 48,8'i erkek olarak belirlenmiştir. Eğitim durumuna bakıldığında $\% 33,8$ gibi bir oranla en fazla ortaokul, ardından \%21,3 gibi bir oranda lise eğitimine sahip bireylerden oluştuğu gözlenmiştir. Katılımcıların \% 65'i evli; \% 35'i bekar olduğu belirlenmiştir. Yine katılımcıların \% 63,7'si eşiyle; \% 11,3'ü çocuklarıyla; \% 22,5'i yalnız; \% 2,5'i ise yardımcısıyla kaldığını,

\% 65'i birlikte; \% 7,5'i ayrı; \% 27,5'i eşinin vefat ettiğini belirtmiştir. Katılımcıların \% 37,5'i eşinin çalışmadığını belirtirken \% 8,8'i memur; \% 7,5'i işçi; \% 8,8'i serbest; \% 37,5'i emekli olduğu belirlenmiştir

Araştırmaya katılanların \% 7,5'inin 1; \% 43,8'i 2; \% 30'u 3; \% 12,5'i 4 çocuğa sahip olduğu, \% 6,3'ünün ise hiç çocuklarının olmadı̆̆ı, yine \% 40'1 1000-1500 tl arası; \% 28,7's 1501-2000 tl arasi; \% 31,3 ‘ü 2001 ve üzeri gelir düzeyi olarak belirlenmiştir.

Tablo 3. Katılımcıların sağlık durumları ve uğraştıkları boş zaman aktivitesine ilişkin yüzdelik değerleri

\begin{tabular}{cccc}
\hline Değişken & n & \% \\
\hline & Psikolojik & 14 & 17,5 \\
Geçirmiş Olduğu Hastalık & Fiziksel & 42 & 52,5 \\
& Herhangi bir hastalık & 24 & 30,0 \\
& geçirmedim & & 78,8
\end{tabular}




\begin{tabular}{cccc} 
Psikolojik Hastalık İçin Tedavi & Evet & 13 & 16,3 \\
Görüldü̈ Mü? & Hayır & 67 & 83,8 \\
\hline Ŭgraştığı Boş Zaman Aktivitesi & Evet & 49 & 61,3 \\
Var Mı? & Hayır & 31 & 38,8 \\
\hline & Sosyal Aktivite & 23 & 28,7 \\
& Sanat Etkinliği & 3 & 3,8 \\
Uğraştığı Boş Zaman Aktivitesi & Spor Aktivitesi & 6 & 7,5 \\
& Kültürel Etkinlik & 5 & 6,3 \\
& Hepsi & 12 & 15,0 \\
& Aktivite Yapmıor & 31 & 38,8 \\
\hline
\end{tabular}

Katılımcıların geçirdiği hastalık durumlarına bakıldığında; \% 17,5'i psikolojik; 4\% 52,5'i fiziksel; \% 30’u hastalık geçirmediğini bildirmiştir.

Geçirilen psikolojik hastalık türü olarak; \% 5'i panik atak; \% 2,5'inde anksiyete; \% 1,3'ünde uykusuzluk; \% 7,5'inde depresyon; \% 5'i unutkanlık; \% 78,8'i hastalık yaşamadığını aktarmıştır. \% 16,3'ü psikolojik tedavi olduğunu belirtirken; \% 83,8'ü tedavi görmediğini bildirmiştir.

Katılımcıların katıldığı serbest zaman aktivite türünü sorgulayan soruya verdikleri yanıtlara bakıldığında \% 61,3'ü serbest zaman aktivitesine katılırken \% 38,8'iherhangi bir etkinliğe katılmamıştır. \% 28,7'i sosyal aktivite; \% 3,8'i sanat etkinliği; \% 7,5'i spor; \% 6,3'ü kültürel etkinlik; \% 15'itüm etkinliklere; \% 38,8'i de aktiviteye katılmadığı belirlenmiştir.

Tablo 4. Katılımcıların sosyo-demografik değişkenlere göre umutsuzluk ölçeği ( $t$ testi) analizleri

\begin{tabular}{|c|c|c|c|c|}
\hline & Değişkenler & $\mathbf{N}$ & Ort. \pm SS & P Değeri \\
\hline \multirow[b]{2}{*}{ Cinsiyet } & Kadın & 41 & $9,58 \pm 5,96$ & \multirow[b]{2}{*}{, 127} \\
\hline & Erkek & 39 & $7,25 \pm 7,49$ & \\
\hline \multirow[t]{2}{*}{ Medeni Durum } & Evli & 52 & $6,94 \pm 6,36$ & \multirow[b]{2}{*}{,006 } \\
\hline & Bekar & 28 & $11,2 \pm 6,84$ & \\
\hline \multirow{2}{*}{$\begin{array}{c}\text { Psikolojik } \\
\text { Tedavi } \\
\text { Görüldü Mü? }\end{array}$} & Evet & 13 & $11,61 \pm 6,89$ & \multirow[b]{2}{*}{, 067} \\
\hline & Hayır & 67 & $7,83 \pm 6,67$ & \\
\hline \multirow{2}{*}{$\begin{array}{c}\text { Serbest zaman } \\
\text { Aktivitesi }\end{array}$} & Var & 49 & $4,69 \pm 5,36$ & \multirow[b]{2}{*}{,000 } \\
\hline & Yok & 31 & $14,38 \pm 4,08$ & \\
\hline
\end{tabular}

Tablo 4'e baktığımızda cinsiyete göre; kadınların umutsuzluk puanları $(9,58 \pm 5,96)$ erkeklerin puanlarına $(7,25 \pm 7,49)$ göre yüksek bulunsa da anlamlı görülmemiştir $(\mathrm{P}=0,127 \mathrm{P}>0,05)$. Evli olanların puanlarının $(6,94 \pm 6,36)$ bekar olanların puanlarına göre $(11,25 \pm 6,84)$ anlamlı derecede düşük olduğu belirlenmiştir $(\mathrm{P}=0,006 \mathrm{P}<0,05)$

Psikolojik hastalık için tedavi görenlerin puanları $(11,61 \pm 6,89)$ görmeyenlere göre $(7,83 \pm 6,67)$ anlamlı şekilde bir farkl111k göstermemiştir $(\mathrm{P}=0,067 \mathrm{P}>0,05)$.

Boş zaman aktivitesi olanların umutsuzluk puanları $(4,69 \pm 5,36)$ olmayanlara $(14,38 \pm 4,08)$ göre anlamlı derecede düşük bulunmuştur $(\mathrm{P}=0,000 \mathrm{P}<0,05)$.

Tablo 5. Katılımcıların kişisel özellikleri ile umutsuzluk ölçeği anova sonuçları

\begin{tabular}{ccccc}
\hline & Değişkenler & n & Ort. \pm SS & P değeri \\
\hline \multirow{2}{*}{ Yaş } & $55-60$ & 19 & $6,73 \pm 6,04$ & \\
& $61-65$ & 27 & $8,11 \pm 6,61$ & \\
& $66-70$ & 25 & $8,04 \pm 7,37$ & ,047 \\
& 70 ve üzeri & 9 & $14,22 \pm 5,01$ & \\
\hline \multirow{2}{*}{ Ĕgitim Durumu } & Okuryazar & 8 & $13,75 \pm 4,39$ & \\
& İlkokul & 25 & $12,16 \pm 6,47$ & \\
\hline
\end{tabular}




$\begin{array}{ccc}\text { Ortaokul } & 27 & 6,96 \pm 6,30 \\ \text { Lise } & 17 & 3,88 \pm 4,97 \\ \text { Üniversite } & 3 & 2,66 \pm 2,51\end{array}$

Tablo 5'te yer alan yaşa gore umutsuzluk ölçek puanları analizlerine bakıldığında; 55-60 yaş arasında olanların puanlarının en düşük $(6,73 \pm 6,04)$, en yüksek puanın ise 70 ve üzerindeki bireylerde $(14,22 \pm 5,01)$ olduğu ve yaşla birlikte oluşan puanlar arası fark analiz edildiğinde ise anlamlı olduğu görülmüştür $(\mathrm{P}=0,047 \mathrm{P}<0,05)$.

Emekli bireylerin eğitim durumlarına göre de umutsuzluk puanlarının ileri derecede anlamlı farklılık gösterdiği belirlenmiştir $(\mathrm{P}=0,000 \mathrm{P}<0,05)$. Eğitim durumu düştükçe umutsuzluk puanlarının da anlamlı derecede düştüğü görülmüştür.

Tablo 6. Katılımcıların ekonomik durumu, sağlık durumu ve uğraştıkları boş zaman aktivitelerine ilişkin umutsuzluk ölçeği anova test sonuçları

\begin{tabular}{|c|c|c|c|c|}
\hline & Değişkenler & $\mathbf{N}$ & Ort. \pm SS & P Değeri \\
\hline \multirow{3}{*}{ Gelir Düzeyi } & $501-1000 \mathrm{tl}$ & 32 & $10,21 \pm 6,69$ & \multirow{3}{*}{, 051} \\
\hline & $1001-1500 \mathrm{tl}$ & 23 & $8,82 \pm 6,79$ & \\
\hline & 1500 tl'den Fazla & 25 & $8,45 \pm 6,81$ & \\
\hline \multirow{3}{*}{$\begin{array}{c}\text { Geçirmiş Olduğu } \\
\text { Hastalık }\end{array}$} & Psikolojik & 14 & $13,42 \pm 6,40$ & \multirow{3}{*}{,007 } \\
\hline & Fiziksel & 42 & $7,78 \pm 6,73$ & \\
\hline & $\begin{array}{l}\text { Herhangi bir hastalık } \\
\text { geçirmedim }\end{array}$ & 24 & $6,70 \pm 6,02$ & \\
\hline \multirow{6}{*}{$\begin{array}{c}\text { Uğraştı̆̆ı Boş } \\
\text { Zaman Aktivitesi }\end{array}$} & Sosyal Aktivite & 23 & $4,60 \pm 5,29$ & \multirow{6}{*}{,000 } \\
\hline & Sanat Etkinliği & 3 & $5,66 \pm 5,03$ & \\
\hline & Spor Aktivitesi & 6 & $1,83 \pm 1,32$ & \\
\hline & Kültürel Etkinlik & 5 & $6,00 \pm 7,38$ & \\
\hline & Hepsi & 12 & $5,50 \pm 6,17$ & \\
\hline & Aktivite Yapmiyor & 31 & $14,38 \pm 4,08$ & \\
\hline
\end{tabular}

Tablo 6'da gelir düzeyine göre umutsuzluk ölçeği puanları karşılaştırıldığında puanlar arasındaki farkın istatistiksel açıdan anlamlı olmadığı saptanmıştır $(\mathrm{P}=0,051 \quad \mathrm{P}>0,05)$. Geçirmiş oldukları hastalık açısından bakıldığında; psikolojik hastalık geçirenlerde umutsuzluk ölçek puanlarının anlamlı farklılık gösterdiği belirlenmiştir $(\mathrm{P}=0,007 \mathrm{P}<0,05)$. Serbest zamanlarında aktivitelere katılım durumuna göre umutsuzluk ölçek sonuçlarının da anlamlı olduğu görülmüştür $(\mathrm{P}=0,000 \mathrm{P}<0,05)$

\section{TARTIŞMA}

Araştırma bulgularına bakıldığında Umutsuzluk duygusu en düşük 55 yaş grubunda olduğu görülürken yaş artışıyla birlikte anlamlı derecede umutsuzluğun da arttığı belirlenmiştir. Bu sonuç kişilik gelişim kuramlarından olan Erikson'un psikosoyal kişilik kuramı açısından değerlendirildiğinde; Erikson'un kuramına uygun bir şekilde 70 ve üzeri bireylerde benlik bütünlüğü azaldığ ve umutsuzluk duygusunun yükseldiği düşünülmüştür. Çalışmamızdaki bireylerin yaş ortalamasının yükssek olması ve katılımcıların emekli olmalarından kaynaklı olarak umutsuzluk puanlarının yaşla birlikte artışında etkili olmuş olabileceği düşünülmüştür. Literatür incelendiğinde de bizim araştırma bulgularımızla benzerlik gösteren, umutsuzluk düzeyi ile yaşın paralel arttığını ortaya koyan çalışmaların olduğu da görülmüştür (Akçöltekin ve Doğan, 2012).

Cinsiyet faktörü açısından umutsuzluk puanları analiz edildiğinde; istatistiksel olarak anlamlı bir farklılık olmadığı tespit edilmiştir. Umutsuzluk ile ilgili literatür incelendiğinde; umutsuzluk puanları üzerinde cinsiyet faktörünün etkisine ilişkin farklı sonuçlar olduğu görülmüş̧ür. Bu çalışmalardan bazıları sonuçlarımızla uyumluluk gösterirken (Şahin, 2019; Tümkaya, 2005; Ulucan, Kılınç, Kaya ve Türkçapar 2011), bazıları da çalışmamızın tersine cinsiyet açısından anlamlı sonuçlar ortaya koymuştur. Bu anlamlı 
sonuçlara ulaşan çalışmaların bazılarında; erkek öğretmenlerin umutsuzluk düzeylerinin kadın öğretmenlere göre daha yüksek olduğu ve erkeklerin bu duyguyu kadınlardan daha fazla yaşadıkları belirtilmiştir (Özben ve Argun, 2003). Anlamlı sonuçlara ulaşan bazı çalışmalarda ise; kadınların erkeklere oranla daha yüksek bir umutsuzluk düzeyine sahip olduğu bilgisine ulaşılmıştır (Tokuç, Evren ve Ekuklu, 2009).

Araştırmadaki örneklem grubunun, umutsuzluk puanları eğitim düzeyi açısından analiz edildiğinde; eğitim seviyesi azaldıkça umutsuzluğun da tam tersine anlamlı derecede arttı̆̆ belirlenmiştir. Özellikle eğitim düzeyi kademe kademe yükseldikçe umutsuzluk puanlarının negatif yönde giderek düşmesi, bu puanlar arasındaki farkın da ileri derecede anlamlı olması, umutsuzluğun eğitim artışı ile birlikte azaldığını göstermiştir. Literatüre bakıldığında; benzer şekilde; eğitim durumu açısından, okur-yazar olanların ve ilkokul mezunu olanların umut seviyesinin diğerlerine göre daha düşük olduğu, eğitim seviyesi arttıkça umut seviyesinin de arttı̆̆ belirtilmiştir (Özben, 2008). Yapılan çalışmalarda eğitim durumu açısından Beck Umutsuzluk Ölçeği toplam puanlarının anlamlı bir şekilde farklılık gösterdiği belirlenmiştir (Şahin, 2019). Literatür bilgileriyle çalışma sonuçlarımız yorumlandığında; eğitim düzeyinin yüksek olmasıyla birlikte bireylerin yapabilecekleri işlerin olasılığının artması, hayata daha bilinçli yaklaşmaları, kendini gerçekleştirme ve üretkenliğin etkisi olabileceği, ancak kesin sonuçlara ulaşabilmek için daha detaylı çalışmaların planlanmasının uygun olacağı düşünülmüştür.

Yine yapılan bir çalışmada okuryazar olmayan ya da ilkokul mezunu olan bireylerin toplumdaki sosyal statüleri, rolleri ve ekonomik koşullarından dolayı umutsuzluğa daha yatkın olabilecekleri, eğitim düzeyi düşük kişilerin problemlerle daha zor başa çıkacakları ve umutsuzluk duygusunu daha yoğun yaşabilecekleri belirtilmiştir (Durak ve Palabıyıkoğlu, 1994; Özben, 2008). Nitekim bu araştırma sonuçları da bizim çalışmamızla paralellik göstermektedir. Bireylerin öğrenim durumları, problemlerle başa çıkmasında, çözüm üretiminde belirleyici bir durum olduğu ve eğitim düzeyi düşük kişilerin, analitik açıdan problemleri çözmede zorlanacakları ve umutsuzluk düzeyi daha yüksek görülebileceği düşünülmüştür.

Sonuçlara bakıldığında; 55 yaş ve üzerindeki bireylerin mesleklerine göre umutsuzluk düzeylerinde istatistiksel açıdan anlamlı farklılık olduğu görülmüştür. Özellikle emeklilik öncesi iş deneyimi olmayanlar lehine anlamlı derece yüksek bulgular tespit edilmiştir. Emeklilikle birlikte işinin olmaması, sosyal ilişkilerini azaltarak yalnızlığa yol açtığı ve kişilerde; farklı duygusal süreçlerin yanında işe yaramazlık ve umutsuzluk duygusu görülebildiği belirtilmiştir (Saygılı, 2017). Umutsuzluk düzeyi ile mesleki doyumu karşılaştıran çalışma sonuçlarına bakıldığında; mesleki doyumu zayıf olanların umutsuzluk düzeylerinin daha yüksek olduğunu (Özben ve Argun, 2003) belirten çalışma sonuçlarının bir nevi bizim çalışmamızdaki sonuçları desteklediği düşünülmüştür.

Medeni durum açısından sonuçlar analiz edildiğinde; umutsuzluk ölçek puanlarının istatistiksel açıdan anlamlı olmadığı görülmüştür. Yapılan çalışmalarda medeni durum ve umutsuzluk düzeyi arasında anlamlı ilişkiler olduğu, evli kişilerin umutsuzluk puanlarının eşinden ayrı, bekar veya eşi vefat edenlere göre daha düşük olduğu belirlenmiştir (Bailey ve Snyder, 2007).

Yaptığımız araştırmadaki örneklem grubunun; gelir düzeyine göre umutsuzluk ölçeği puanları karşılaştırıldığında anlamlı bir fark olmadığı belirlenmiştir. Bu çalışmamızla paralel sonuçlar ortaya koyan araştırmada (Mangır, Aral ve Aksoy, 1990); gelir durumunun umutsuzluk üzerinde etkili olmadığı ifade edilmiştir. Bu şekilde bulgularımızı destekleyen çalışmaların tersine; algılanan gelir düzeyi açısından umutsuzluk ölçeği puanlarının istatistiksel açıdan anlamlı olduğunu saptayan çalışmalar da mevcuttur (Şahin, 2019). Yine geliri az olan bireylerin umutsuzluk puanlarının geliri fazla olan bireylerden daha yüksek olduğu (Özben ve Argun, 2003) da belirtilmiştir. Düşük ve orta gelir düzeyi grubunda yer alanların umutsuzluk puan ortalamaları ile yüksek gelir düzeyi grubunda yer alanların puan ortalamaları arasındaki farkın anlamlı olduğu belirtilmiştir (Duman, Taşğın ve Özdağ, 2009). Bulunan bu sonuçların da bizim çalışmamızla örtüşmediği görülmektedir. Gelir düzeyi açısından umutsuzluk ölçeği toplam puanları arasındaki fark istatistiksel olarak anlamlı bulunmuştur (Şahin, 2019).

Yapılan bu araştırmada 55 yaş ve üzerindeki bireylerin geçirmiş oldukları hastalıklara göre umutsuzluk puanları anlamlı farklılıklar göstermiştir. $\mathrm{Bu}$ sonuç değerlendirildiğinde yaşlılıkla birlikte hastalıkların oluşması, sağlık durumunun değişmesiyle birlikte umutsuzluk düzeylerinde de artışa 
neden olduğu sonucunu çıkartabiliriz. Hastalık geçirme durumuna göre umutsuzluk puanları anlamlı farklılık gösterirken; tedavi görme açısından anlamlı bir sonuca ulaşılmamıştır. Literatürde de bu konuya ilişkin detaylı bir çalışmaya rastlanmamıştır.

Yaşlıların serbest zamanlarında bir etkinliğe katılıp katılmama durumlarına göre umutsuzluk düzeyleri analiz edildiğinde; serbest zaman diliminde herhangi bir aktiviteye katılanların umutsuzluk puanları katılmayanlara göre anlamlı derecede düşük bulunmuştur. Emekli bireylerin serbest zamanda ne tür etkinliklere katıldıkları ve bu katıldıkları etkinlik tipi açısından umutsuzluk duygularında bir farklılaşma olup olmadığına bakıldığında ise; serbest zamanda devam edilen aktivite harekete dayalı ise umutsuzluk puanlarının düştüğü görülmüştür. Özellikle spor yapanlarda umutsuzluk düzeyinin en düşük seviyede çıkması ve en yüksek umutsuzluğun da serbest zamanlarında herhangi bir aktiviteye katılmayanlarda görülmesi, kişilerin serbest zamanlarında hareketli etkinlik seçmelerinin umutsuzluğu gidermede önemli olduğunu göstermiştir. Literatüre bakıldığında ise; serbest zaman aktivitesi olanların her hangi bir serbest zaman aktivitesi olmayanlara göre umut düzeyinin daha yüksek olduğu, bahçe işleri gibi uğraşların olmasının yaşlılarda duygu durumunun iyileşmesinde önemli katkı sağladığı ve özellikle sosyal ilişkileri geliştirmede etki ettiği belirtilmiştir (Yee Tse, 2008; Özben, 2008).

Özellikle kitap okuma, sanatsal ve kültürel etkinliklere katılma, film izleyerek zaman geçirme gibi serbest zamanı etkin bir biçimde değerlendirenlerin umutsuzluk düzeylerinin serbest zamanda hiçbir aktiviteye katılmayanlara göre daha düşük olduğu belirtilmiştir (Özben ve Argun, 2003). Literatürdeki bu bilgiler ve araştırma sonuçları karşılaştırıldığında serbest zaman etkinliklerinin umutsuzluğu gidermede etkili olduğu ve kesin sonuçlara ulaşabilmek için de daha detaylı çalışmaların planlanmasının uygun olacağı düşünülmüştür.

Serbest zamanda yapılan aktiviteler eğer grup halinde yapılıyorsa, umutsuzluğu gidermede daha etkili olacağı belirtilmiş. Grup halinde yapılan etkinliklerin; yalnızlı̆̆ 1 giderdiği ve bir tür sosyal destek ağ yarattığı, bir tür meşguliyet imkanı sağladığı ve bu şekilde kişilerin kendine yönelen dikkatlerinin yaptıkları etkinliğe yöneltecekleri açıklanmıştır. Bir şeyler üretme etkinliği sonucunda da; kendini daha iyi hissetme, yaşama yönelik umut duygusu geliştirecekleri, fizik aktiviteye ve hareketli bir etkinliğe katılım ve bu katılımın da 20 dakika devam etmesi sonrasinda seratonin hormonunu salgılatarak iyi hissetme duygusunu geliştirdiği yönündeki literatür bilgilerini de (Baltaş ve Baltaş 1990) desteklediği düşünülmüştür.

\section{SONUÇ VE ÖNERILER}

Bu çalışma 55 yaş ve üzerindeki bireylerin serbest zamanlarında herhangi bir etkinliğe katılıp katılmama ve çeşitli sosyo-demografik özelliklere göre umutsuzluk düzeylerinin incelenmesi üzerine yapılmıştır. Katılımcıların; cinsiyet, gelir düzeyi, tedavi görme durumlarına göre umutsuzluk puanlarını anlamlı farklılık göstermediği belirlenmiştir.

Bireylerin yaşı arttıkça umutsuzluk puanının da bu artışa orantılı olarak arttığı görülmüştür.Özellikle 70 ve üzeri yaş grubunun umutsuzluk puanının en yüksek grup olduğu tespit edilmiştir. Eğitim seviyesi düştükçe umutsuzluk düzeyinin arttığı, evli olanların bekar olanlara göre umutsuzluk puanlarının daha düşük olduğu tespit edilmiştir. Katılımcıların geçirmiş oldukları hastalık olup olmamasına göre umutsuzluk puanları arasında anlamlı fark olduğu görülmüsşür. Psikolojik hastalık geçirenlerin, fiziksel hastalık geçiren ve hiç hastalık geçirmeyenlere göre umutsuzluk puanlarının daha yüksek olduğu belirlenmiştir.

Aktiviteye katılma durumlarına gore emekli bireylerin umutsuzluk puanlarına bakıldığında; aktiviteye katılanların umutsuzluk puanlarının aktiviteye katılmayanlara gore düşük olduğu belirlenmiştir. Serbest zamanlarında özellkle spor aktivitesine katılanların umutsuzluk puanlarının en düşük olduğu belirlenmiştir.

Sosyal destek azlığının fiziksel ve duygusal sorunlara yol açtığı, bu sorunlar içerisinde; yalnızlık, günlük yaşam aktivitelerinin azlığı, sağlık sorunları, bilişsel bozukluk ve depresif belirtiler olduğu bildirilmiştir (Choi, Kong and Jung, 2012). 
$\mathrm{Bu}$ araştırmanın bulguları serbest zamanda herhangi bir etkinliğe katılımın umutsuzluk duygusunu azaltmada önemli olduğunu göstermiştir. Umutsuzluk, sosyal aktiviteye katılım ve sosyal destek ağ1 ilişkisini araştıran daha detaylı çalışmaların yapılması bu konuda daha işe yarar bilgiler sunacaktır.

Tüm bu sonuçlar ve literatür bilgileri göz önüne alındığında sosyal destek ağının arttırılması açısından emekli bireylerde rekreatif etkinliklerin yaygınlaştırılması önemli görülmüştür.

Bilgilendirme / Acknowledgement: Bu çalışma, ilk yazarın lisans tez bitirme çalışması olarak hazırlanmış ve 1 . Uluslarası Rekreasyon ve Dans Kongresinde Poster Bildiri olarak sunulmuştur.

\section{KAYNAKÇA}

Akçöltekin, A. ve Doğan, S. (2012). Sınıf öğretmenlerinin umutsuzluk düzeylerinin farklı değişkenler açısından incelenmesi. The Journal of Academic Social Science Studies. 5 (7), 49-59.

Aslan, M. ve Hocaoğlu, Ç. (2017). Yaşlanma ve yaşlanma dönemiyle ilişkili psikiyatrik sorunlar. Düzce Üniversitesi Sağllk Bilimleri Enstitüsü Dergisi, 7(1), 53-62.

Bailey, T.C. and Snyder, C.R. (2007). Satisfaction with life and hope. The Psychological Record, 57, 233-240.

Baltaş, A. ve Baltaş, Z. (1990). Stres ve başa çıkma yolları. İstanbul: Remzi Kitabevi.

Bilir, N. ve Paksoy Erbaydar, N. (2015). Halk sağlı̆̆ temel bilgiler 3. (Ç. Güler, L. Akın, Eds.). Yaşl11ık sorunları ve bulaşıcı olmayan hastalıkların kontrolü. Ankara: Hacettepe Üniversitesi Yayınları, $1528-1556$.

Choi, M.,, Kong, S., and Jung, D. (2012). Computer and internet interventions for loneliness and depression in older adults: a meta-analysis. Healthc Inform Res., 18(3), 191-198. 10 Ekim 2019 tarihinde https://synapse.koreamed.org/search.php?where=aview\&id=10.4258/hir.2012.18.3.191\&code=1 088HIR\&vmode=FULL adresinden erișildi.

Dilbaz, N. ve Seber, G. (1993). Umutsuzluk kavramı: depresyon ve intiharda önemi. Kriz Dergisi, 1, 134-138.

Duman, S., Taşğın, Ö. ve Özdağ, S. (2009). Beden eğitimi ve spor yüksekokulu spor yöneticiliği bölümünde okuyan öğrencilerin umutsuzluk düzeylerinin incelenmesi. Selçuk Üniversitesi Beden Eğitimi ve Spor Bilim Dergisi, 11(3), 27-32.

Durak, A. ve Palabıyıkoğlu, R. (1994). Beck umutsuzluk ölçeği geçerlilik çalışması. Kriz Dergisi, 2(2), 311-319.

World Health Organization (2015). World report on aging and health. 20 avenue appia, 1211 Switzerland: Geneva 27.

Kocaman, N. (2008). Tıbbi hastalığa psikososyal tepkiler, İstanbul Tıp Fakültesi Dergisi, 71, 52-58.

Kutlu, M. (1998). Özürlü çocuğu olan ana babaların umutsuzluk düzeyleri. Yayınlanmamış doktora tezi, Ondokuz Mayıs Üniversitesi, Sosyal Bilimler Enstitüsü, Samsun.

Landeiro, F., Barrows, P., Musson, E.N., Gray, A. M. and Leal, J. (2016). Reducing social isolation and loneliness in older people: a systematic review protocol. BMJ Open, 2017;7:e13778. doi:10.1136/bmjopen-2016-013778. $10 \quad$ Ekim $2019 \quad$ tarihinde https://bmjopen.bmj.com/content/bmjopen/7/5/e013778.full.pdf adresinden erişildi.

Mangır, M., Aral, N. ve Aksoy, A. (1990). Ankara Üniversitesi Ziraat Fakültesi Ev Ekonomisi Yüksek Okulu ile Tarımsal Mekanizasyon Bölümü birinci sinıf ögrencilerinin depresyon durumlarını etkileyen bazı etmenler üzerine bir araştırma. Ankara: Ankara Üniversitesi Ziraat Fakültesi Yayınları. 
Öz, F. (2002). Yaşamın son evresi: Yaşl1lık psikososyal açıdan gözden geçirme. Kriz Dergisi, 10(2), 1728.

Öz, F. (2010). Sağlık alaninda temel kavramlar ve beceriler. Ankara: Mattek Matbaacılık.

Özben, Ş. (2008). Yaşl1larda umutsuzluk. Dokuz Eylül Üniversitesi Buca Eğitim Fakültesi Dergisi, $23,136-151$.

Özben, Ş. ve Argun, Y. (2003). İlköğretim öğretmenlerinin umutsuzluk ve tükenmişlik düzeyleri. Ege Ĕ̈itim Dergisi, 1(3) 36-48.

Saygıl1, S. (2017). Yaşlllık psikolojisi. İstanbul: Türdav Yayın Grubu. 21-42.

Savaşır, I. ve Şahin, N. (1997). Bilişsel-davranışçıl terapilerde değerlendirme:sık kullanılan ölçekler. Ankara: Türk Psikologlar Derneği Yayınları.

Steptoe, A., Shankar, A., Demakakos, P. and Wardle, J. (2013). Social 1solation, loneliness, and all-cause mortality in older men and wome. Proceedings of The National Academy of Sciences of The United States of America, 110(15), 5797-5801.

Şahin, M. A. (2019). Yaşlı Bireylerde sosyal destek alglsının yalnızllk ve umutsuzluk üzerine etkisi. Yayımlanmamış yüksek lisans tezi, Erzincan Binali Yıldırım Üniversitesi Sağlık Bilimleri Enstitüsü Hemşirelik Anabilim Dalı, Erzincan.

Tanç, S. (1999). Benlik değeri, umutsuzluk ve kariyer beklentileri. Yayımlanmamış yüksek lisans tezi, Marmara Üniversitesi, Sosyal Bilimler Enstitüsü, İstanbul.

Tümkaya, S. (2005). Ailesi yanında ve yetiştirme yurdunda kalan ergenlerin umutsuzluk düzeylerinin karşılaştırılması. Türk Eğitim Bilimleri Dergisi, 3(4), 445-459.

Tokuç, B., Evren, H. ve Ekuklu, G. (2009). Edirne ve Hayrabolu Mesleki Eğitim Merkezi öğrencilerinde umutsuzluk ve sürekli kaygı düzeyleri. TAF Prev Med Bull, 8(2),155-160.

Ulucan, H., Kılınç, M., Kaya, K. ve Türkçapar, Ü. (2011). Beden eğitimi ve spor yüksekokullarında öğrenimlerine devam eden öğrencilerin umutsuzluk ve yaşam doyumlarının incelenmesi. Selçuk Üniversitesi Beden Eğitimi ve Spor Bilim Dergisi, 13(3), 349-356.

Yee Tse M. M. (2008). Therapeutic effects of an indoor gardening programme for older people living in nursing homes. Journal of Clinical Nursing, 19, 949-958.

Yıldırım, B. (2015). Öğretmenlerin umutsuzluk düzeylerinin incelenmesi. Yayımlanmamış yüksek lisans tezi, Okan Üniversitesi Sosyal Bilimler Enstitüsü. İstanbul. 